\title{
Bataille in the South: James Agee's Let Us Now Praise Famous Men and Erskine Caldwell's Depression Fiction
}

\begin{abstract}
This article tries to show how James Agee in Let Us Now Praise Famous Men (1941) and Erskine Caldwell in his fiction from the Depression years - especially the little-known novella, The Sacrilege of Alan Kent (1930) - used a discourse of the sacred to represent the strange otherness of the Depression South. They particularly drew on the "left hand sacred" (of taboo, repulsiveness and sacrifice) as distinct from the "right hand sacred" found in institutional religion. The article argues that a theoretical understanding of Agee and Caldwell's use of the sacred may be provided by Georges Bataille. It seems particularly appropriate to invoke Bataille since he was concerned with the political elements of the sacred and sought to mobilize these elements during the 1930s when liberal democracy was thought by many leftist writers on both sides of the Atlantic to have failed. Bataille provides a productive analogue to the two southerners, who shared this perception of liberal democracy, because he tried to articulate a radical path in this decade that was not Marxist. Agee and Caldwell, although notionally Communist, were dissatisfied with Marxism because they saw it as another version of a utilitarian or restricted economy. They looked instead to the sacred as a discourse of transgression - a discourse that was rooted in what Bataille called a general economy or the deeper organization of collective life around ecology and the gift.
\end{abstract}

Keywords: the sacred, transgression, heterology, southern agriculture in literature, the Depression.

A region is more than a geographic or political division: it also is a spatial fantasy, a fantasy produced by certain figurative practices that arise within a historical context. A fundamental figure for the American South of the 1920s and 1930s, notably found in William Faulkner (in such works as "The Tall Men" [1941]) and the Nashville Agrarians, was that of the restorative earth and of its natural wealth. But a fundamental problem with this conservative figure of the earth was that by the time of the Depression years of the 1930s, which struck cotton agriculture in particular, it had become counter-historical and even utopian. In response to this belated Jeffersonianism of so many of the major figures of the Southern Renaissance, a minority of southerners on the political left developed a more subversive variety of writing about the earth and tried to find radical literary forms to respond to the devastation of agricultural depression. James Agee's study Now Let Us Praise Famous Men (1941) (hereafter shortened to Praise) and Erskine Caldwell's fiction, notably Tobacco Road (1932), were harsh human documents that focused on white cotton tenants (not the small farmers favoured by the Agrarians) and on their impoverished place in the debt structure of southern agriculture. The political point of view informing these works of Agee and Caldwell was close to Communism: indeed Agee called himself "a Communist by sympathy and conviction" and Caldwell advocated a collectivization of agriculture by the state (Agee, Praise 249; Caldwell, Tenant 29). Yet the forays of these two writers into a surrealist aesthetic (automatic writing, use of the illogic of dreams in narrative) is far 
from the proletarian realism favored by such northern literary radicals as Mike Gold and magazines like The New Masses. ${ }^{1}$ One could go further and argue that Praise and Tobacco Road reach beyond the narrow political categories of dissent available in the America of the 1930s and draw on the transgressive energies of the sacred as described by Georges Bataille, the renegade surrealist and founder of the College of Sociology. For Bataille, the sacred was a heterological structure that defined itself in opposition to the profane (the utilitarian or servile: the political meaning is uppermost for Bataille in the 1930s). It is unlikely that either Agee or Caldwell read Bataille, whose work went virtually untranslated into English in the interwar years. But, arguably, the theories of Bataille concerning transgression, sovereignty, and the need for wasteful expenditure are applicable to Agee and Caldwell, particularly when one considers that Bataille's theories were explicitly formulated as political responses within the context of the failed democracies of the 1930s and that this context is implicit in the writings of Agee and Caldwell. ${ }^{2}$ The intention of this article is to examine these two radical authors of the southern earth for their transgressive expression of an "other" south, defining "other" as a heterogeneity that is pitted against the homogeneous. By homogeneous is meant all varieties of the rational, scarcity-based economy possible in the 1930s South: plantation agriculture and its post-bellum offshoot, the sharecropping system; New Deal welfarism; Communist state planning; and the Jeffersonian agrarianism of the Nashville school.

One potential confusion should be cleared up, particularly since some southern writers such as Allen Tate and Flannery O'Connor have said that twentieth-century southern writing rests on an implicit foundation of religious orthodoxy. For Bataille,

1 Agee's preoccupation with surrealism - for example his experiments with automatic writing - has been studied by Hugh Davis (51-72). A pre-publication extract from Praise ("Colon") appeared in James Laughlin's anthology New Directions in Prose and Poetry 1940, a journal intended to be "an exhibition gallery for new trends and techniques" (Laughlin xiii), especially those of the European avant-garde, and which included nearly two hundred pages of "A Surrealist Anthology" and a long essay on surrealism by Kenneth Burke. Both Davis (93) and Leigh Anne Duck ("Arts" 293, 299) discuss Agee's similarity to Bataille, although neither mentions the sacred as the central concept that they hold in common. Caldwell was likened by Kenneth Burke to the Surrealists in an article on Caldwell in 1937. The definitions of surrealism in this article are further developed in Burke's 1940 essay on surrealism ("perspective by incongruity," the nonlogic of dreams, "gargoyle-thinking") (Burke, "Surrealism" 575). As Chris Vials points out, the use of "the magical" and of allegorical characters in Caldwell's fiction contrasts with the dialectical naturalism sponsored by most proletarian novelists of the 1930s (Vials 82-83).

2 Georges Bataille was rarely published or discussed in English in Agee's lifetime. One exception is a translation of "The Sacred Conspiracy" by Georges Duthuit in Eugene Jolas's 1941 yearbook, Vertical: A Yearbook for Romantic-Mystic Ascensions, a work that Agee might conceivably have read since he was intrigued by the surrealistic importations appearing on the New York artistic scene. Another exception was Bataille's "On Hiroshima" published in Dwight Macdonald's journal Politics (July-August 1947, 147-150), an essay on the existential implications of the Bomb that had similarities to Agee's famous Time article of August 1945 on this subject. Agee was most probably aware of Bataille's "Le Souverain," a major theoretical exposition of the rebellious sovereign self, because it appeared in the same volume of Botteghe Oscure, the Rome-based international journal, as did Agee's short animal fable of the Holocaust, "A Mother's Tale" (1953, volume 9). But it seems that neither Agee nor Caldwell ever mention Bataille in their published writings. 
the sacred is different from the religious sense of the word affirmed by Tate and others in that Bataille's definition of the sacred rejects the transcendence of orthodox Christianity and derives from the most material of materialisms, or what Bataille called base materialism. The sacred for Bataille is an energy latent within the collective material body and is released in such total impulses as disgust, the erotic, laughter and madness. These can produce a social "effervescence" (to use Emile Durkheim's term [407]) that breaches the psychological controls of the utilitarian society and its results may be revolution, festival, or inner experience (a meditative overcoming of the everyday ipseity of the self). Both Agee and Caldwell show the closeness of their poor whites to an immanent force that permeates base matter: a force that holds them in what is both a destructive and regenerative relation to southern soil. The presence of this sacred force in these writings is the reason why Kenneth Burke refers to a "balked religiosity" in Caldwell's work and why Agee so assiduously seeks to find evidence of "human divinity" in the cotton tenants (Burke Philosophy 351; Agee Praise xiv). Despite the numerous differences of idiom and cultural context between Bataille's dense philosophical construction of an atheology and the more experiential focus of the two southerners, it is evident that all three writers converge in their marked preoccupation with the sacred in a secular age. For them the sacred, however, does not mean the anachronistic beliefs of a primitive society but the expression, in modern life, of intense collective forms of the social body.

For these writers, therefore, it is the political aspect of the sacred that is significant. The most notorious scene in Caldwell's oeuvre, the scene from God's Little Acre (1933) where the striking loom-worker Will Thompson strips the clothes off his brother-in-law's wife Griselda and tears them into pieces of lint, can be read as a scene of Bataillean transgression. Will's destruction of a machine-made object - its reversal from commodity into raw material - is both wasteful expenditure and, at the same time, an assertion of proletarian virility. Will goes on to have sex with the willing Griselda, an erotic transgression that on the next day carries over into a political one when Will leads the strikers in a takeover of the mill (Will's throwing his ripped up shirt out of the factory window and "turn[ing] on the power" are also acts of proletarian virility [Caldwell God's 245]). Ty Ty Walden, the impoverished farmer who is Caldwell's spokesman on religious matters in the novel, does not hesitate to ascribe Will's extramarital sexual cravings to "the God inside of a body," the interior space of transgression that is its own sacred sanctification (Caldwell, God's 269).

One could argue that in the Will-Griselda scene the Bataillean act of transgression has been softened and compromised by the demands of a mass readership. Certainly most recent critics of Caldwell's work have expressed unease with his voyeuristic manipulation of the stereotypes of male desire found in the popular fiction of the 1930s (for example, Vials 85). But in an early experimental novel by Erskine Caldwell, The Sacrilege of Alan Kent (henceforth Kent), a novel written at the turn of the 1930s, the Bataillean sacred stands out with sharper definition, and the "God inside" is not identified with Will's male hedonism but with the anguish of self-sacrifice. In his apprenticeship phase in the late 1920s Caldwell was searching for a "new ground" of modernist form and he published Kent from 1929 to 1931 in two avant-garde American publications: the yearbook New American Caravan (the first installment) and the 
little magazine Pagany (the last two installments) (Caldwell, Conversations 283). The novel, with its present title, subsequently appeared in the short story collection American Earth (1931) and then as a separate short novel in $1936 .{ }^{3}$ It is a first-person account of a transient who, after a troubled childhood as the son of a clergyman, wanders across a scarred South, moving from job to job as farm laborer, as railroad builder or as restaurant worker. In the process he is the casual witness of murder, lynching, fatal accidents, and prostitution. After an attempt to return to his parents' house, only to find they have disappeared, and after a brief liaison with an elusive woman-muse who then dies, he is left with a final sense of abandonment: "I knew I would always be alone in the world" (Caldwell, Kent 57).

The form mirrors this peripatetic story: instead of telling a connected narrative, it is divided into three chapters of brief, numbered fragments, each containing a small episode or description (an "imagistic concatenation" in Kenneth Burke's description of the surrealist text [Burke, "Surrealism," 565]). ${ }^{4}$ This is an appropriate form for a narrative in which the heterogeneous part breaks off and revolts against the whole (Burke calls this Caldwell's "cult of incongruity" or "his deft way of putting the wrong things together" and he finds evidence for it even in Caldwell's supposedly naturalistic works, which he prefers to call works of "magic" [Burke Philosophy 352, 355, 358]). Kent's life is made up of gratuitous events that appear and pass: they can be sudden incursions of violence (for example, the murder of the construction camp prostitute for her money) or little epiphanies of what Burke calls "purest poetry" ("Once the sun was so hot a bird came down and walked beside me in my shadow") or micro-stories of the ordinary ("A man walked in a restaurant through the front door and ate all he wanted to eat") or even such super-real happenings as Kent's observation of a man leaping to the moon from a hilltop (Burke Philosophy 351; Caldwell Kent 25, 33). Overall the work is one long staging of the loss of the self. It presents Kent's life as an act of "sacrilege," a desecration that is heightened by his being the son of a clergyman. The accidents that befall Kent - for example, in his childhood he spills hot sausage grease onto himself, which burns "deep red holes" in his flesh, and in his early adulthood he is left with "a scar on [his] eyes" by a glimpse of the muse-woman, Florence - all seem like the acts of auto-mutilation that Bataille noted in his essay on Vincent van Gogh: "the necessity of throwing oneself or something of oneself out of oneself" (Bataille, Visions 67; Caldwell, Kent 8, 42). In other words, Kent turns sacrifice, that supreme act of non-productive expenditure in Bataille's scheme of the sacred, on himself and in so doing breaks open the homogeneity of the self, its function as a thing in a servile

3 The novel is seen by Guy Owen as Caldwell's "strangest, and in some ways, most original book" (46) while Sylvia Jenkins Warner says it "deserves a larger audience" (31). Despite these recommendations of several decades ago, the novel remains largely undiscussed in southern literary studies.

4 Burke's "imagistic concatenation" might be compared with Rodolphe Gasché's comment on "phantasm" in Bataille's fiction. "Phantasm," says Gasché, depends on the deliberate materialization and desublimation of the poetic image; such images are "divided and separated from each other" and do not add up to a unity that can be grasped as an integrative concept or as beauty (Gasché 150). This process of katabolic fracturing Gasché calls "sacrilege" (157), a term clearly applicable to Kent. 
economy. ${ }^{5}$ Kent welcomes his torment and says that if his "soul" were not torn apart by this "painful hunger" it would die "from lack of food" (Caldwell, Kent 43).

But, says Kent, his land - the South - is also a "sacrilege." It is the unhallowed ground from which "throwaway bodies" - often black bodies - emerge and indifferently return (Yaeger 15). In a way that is unmatched in a literary work published by a white southerner in 1930 there is a frank admission of the sadism of the southern racial order: for example, Kent witnesses some men lynch a black boy and take body parts for souvenirs (this custom had been described in newspaper accounts of lynchings, but probably not in literary writings before), then later observes the sexual abuse of black women workers by a southern landowner who goes back to the times of slavery by putting them in chains (when the landowner burns one woman with a hot poker, Kent and a black worker shoot him). Caldwell was that relatively rare white writer in the interwar South: an absolute dissenter from all forms of Jim Crow. In a later novel, Trouble in July (1940), he expanded the brief oneiric horror of the lynching in Kent into a perceptive psycho-social analysis of the white supremacist mob and its emotional manipulations of criminal "evidence" (at the end of the novel this mob would rather not face having to understand the confession of the white woman, who admits that she told a lie about the black youth whom they have just lynched, and they kill her as well). ${ }^{6}$

So Kent's earth longings in the narrative - his need to feel "part of the roots that lived" - are longings for what is a criminal earth (Caldwell, Kent 48). ${ }^{7}$ The toxic redness of this soil, constantly emphasized by Caldwell in Kent, is a historical index of the agricultural depression in the late 1920s and 1930s: the red "gashes" point to overcultivation of cotton as a single cash crop. ${ }^{8}$ In the opening sentences of the narrative Kent's birth during a downpour of rain becomes a Bataillean tear in the order of being: "Rainwater had soaked the red earth so that the world might bleed to death" (Caldwell, Kent 7). This contagious red quickly spreads to the sun and to fire, those other symbols of non-productive expenditure in Bataille's writing. Kent's childhood home is burnt in a "red" bush fire; and he is rescued and deposited in "red mud" while his dog is burnt alive (Caldwell, Kent 11). Self-mutilation and the energy of the sun are conjoined at the end of the first section when it is the sun that bites the narrator's "eyeballs" and his blood "drips over all over the world" (Caldwell, Kent 21). ${ }^{9}$

5 Kent, however, is not some passive Christ-child like Faulkner's Benjy: he himself murders workers at the behest of his employers (a black worker who falls ill; an ineffectual fortune teller at a circus) and he has illegitimate children of whom he loses track. Such behavior, however, can be seen as part of his project of auto-destruction.

6 Erskine Caldwell, Trouble in July [1940] (Savannah: Beehive P, 1977).

7 For Bataille, the earth is intrinsically criminal since its constituent of base matter "can only be defined as the nonlogical difference that represents in the relation to the economy of the universe what crime represents in relation to the law" (Bataille, Visions 129).

8 The sociologists Arthur Raper and Ira de A. Reid in Sharecroppers All (1941) see the "red gashes" in southern agricultural land as an ecological sickness that mirrors that of a stultified and segregated social order (Raper and Reid 220).

9 In "Rotten Sun" Bataille presents the sun as a maddening, excremental excess much like "a mental ejaculation, foam on the lips, and an epileptic crisis" (Bataille, Visions 57). The sun, for both Bataille and the southerners, is the type both of crippling loss (as in Kent's predator sun) and of a 
The sacrilegious South is never far below the sociological surface of James Agee's Praise. Perhaps when Agee first started on his project in the summer of 1936 he wanted to produce a more scientific account of the tenants of the kind associated with New Deal ethnography and with the fact-collecting work of such federal agencies as the Farm Security Administration. But Agee came to see this point of view as very limited and he mocks its representatives in Praise as those who support "well-thoughtout liberal efforts to rectify the unpleasant situation down South" (Agee, Praise 14).

The reason for his passionate dissent from such "liberal efforts" is that Agee discovered that the enormity of the condition of the tenants was so overwhelming that it turned round and devastated the whole presumption of a rational economy. This makes it "obscene" for outsiders, including himself, to "pry intimately into the lives of an undefended and appallingly damaged group of human beings" (Agee, Praise 7). What cuts off the three tenant families of Alabama that Agee describes - the Gudgers, the Woods, and the Ricketts - is a force field of taboo and abjection that attaches itself to poverty and which, following the ancient Latin sense of sacer (that which must be kept separate), can be described as the antipathetic domain of the sacred. For Agee, one cannot report on these southern poor whites in a calm, neutral manner. In his "Preamble" to Praise he sets out what is essentially a Bataillean method of transgressive writing for his book: he wants to write in a way that is "beyond any calculation savage and dangerous and murderous to all equilibrium in human life" (Agee, Praise 16). Therefore he has to draw on every resource to scandalize the liberal reader, to do the equivalent of jamming this reader's ear against a gramophone playing a Beethoven symphony: "You won't hear it nicely. If it hurts you, be glad of it" (Agee, Praise 16).

Agee uses various strategies to induce this hurt. One is that he mediates his account through a martyr-figure of a narrator, who goes out of his way to wound himself in dramatic mimesis of the tenants' plight (for example, he seemingly enjoys being eaten by bed bugs at the Gudgers). But Agee's main strategy is to show how the three families are ravaged by what Durkheimian sociology had called "the left hand sacred." Early Durkheimians distinguished between "the right hand sacred" (official, hierarchical) and the "left hand sacred" (repulsive, transgressive); Bataille, taking up his legacy in a renegade way, became a partisan of the latter category. Agee certainly has moments when he sees the tenants as the angels or priests of the right hand sacred, but within this apparently Catholic piety the transgressive elements of the left hand version are barely concealed. The proximity is there to see, for example, when Agee, staying with the Gudgers overnight, notices how the family Bible has a cold smell of excrement. He also records, for example, how the clothes and bodies of the Ricketts family are "insanely ... dirty" and how the tenants' food seems "unclean, sticky, and sallow with some sort of disease," causing "a quiet little fight ... on your palate and in the pit of your stomach" (Agee, Praise 197, 416). He observes the surrealist menace of the domestic objects that the Gudgers hoard in their cupboards, such as the chipped china dolls, or of the detritus that collects under their home, such as the "bone button, its two eyes torn as one" (with its Bataillean frisson of enucleation) (Agee, Praise 147). The left hand sacred also permeates the nauseating labor of cotton farming: for example,

glorious expenditure of energy. What appears, to use Bataille's terms, to be self-destructive within a restricted economy can be transformed into a generative force within a general economy. 
the cotton, when it is ripe, "vomit[s]" forth into white balls, and Agee observes that the mules are so crushed beneath "hopeless work" that they have a "Mongolian look" that derives, according to Agee, from being "part insane" (Agee, Praise 336, 212, 216). There is also an oft-repeated emphasis on the wounded bodies of the tenants (for Bataille, the wound is a mode of communication between individuals that opens each person up to the other as part of a collective of emptied out selves). Wounds, dirt, rags, and excrement are all variations of what Bataille called the "formless," or the actual being of the object when considered outside of the "mathematical frock coat" of form imposed by "philosophy" (Bataille, Visions 31). When seen from the perspective of base, rather than idealistic, materialism all objects appear not as stable forms but as something like "a spider or spit" (Bataille, Visions 31). Agee even wants to do away with the very representational structure of writing so as to be able to merge with such "formless" objects. In "Preamble" he notoriously says that he wishes he could do no writing at all but simply present "fragments of cloth ... lumps of earth ... phials of odors, plates of food and of excrement ... A piece of the body torn out by the roots" (Agee, Praise 13). Such a wish is much closer to Bataille's materialistic, deviant surrealism than the dream surrealism of the movement's founder, André Breton, whose vision was rooted in romantic idealism. Agee indeed presents an anti-aesthetic, claiming that it is the role of literature to describe "the cruel radiance of what is" and not to imagine other worlds, and he asks of the reader, "Above all else ... don't think of it as Art" (Agee Praise 11, 15). "Art" is another way of assimilating the absolute singularity of the tenants and their manifestation of "the cruel radiance of what is" into a universal or homogeneous standard of beauty and thereby achieving "the emasculation of acceptance" amongst his readership (Agee, Praise 13).

The question is: why, for Agee and Caldwell, should it be the South, and particularly the agricultural South, that is associated with the sacred? A likely explanation is that the otherness of the South, its essential difference from the rest of the nation, can be readily mapped onto the differential structure of the sacred. The sacred, for Bataille and the College of Sociology, is a relation of difference, one that is solely constituted by its opposition to that which is profane and normative. The South has historically been perceived as an internal other, a backward region within a nation of liberal modernity (the interwar South was the "nation's region," according to Leigh Anne Duck, or an "internal orientalism" according to David R. Jansson). The Depression of the 1930s sharpened this contrast, particularly since the New Deal took the South as, in President Roosevelt's expression of 1938, the nation's "No. 1 economic problem" (quoted in Leuchtenburg 104). In other words, the poor whites were a heterogeneous class within a heterogeneous region - they were southern heterogeneity doubled. The land on which the tenants lived seemed located in a different time and space. Duck argues that "Caldwell was centrally concerned with the social and characterological effects of uneven development - the radical geographic divergences within the process of U.S. modernization" and that this "uneven development" was projected as a spatial and temporal estrangement onto "regional grotesques" such as the Lester family (Duck, Region 86, 87). Agee's method of appraising the non-synchrony of the agricultural south was undoubtedly more sophisticated than Caldwell's. He opens out the life of three tenant families from Alabama in all its micro-logical predicament and gives a 
sense of the insoluble, tragic depths of poverty. This poverty seems to have its origin outside the political reach of any "cure" and its taint is biological in nature, reaching down into the eugenic source of broken being as it rises from the early sea-bed of life (Agee, Praise 207).

There is a well-established critical lexicon for the literary expression of the otherness of the South: the grotesque, the southern gothic, the freak, the abject (in Julia Kristeva's sense). But in all of these terms the historical configuration of otherness tends to get deflected into formal or psychoanalytical terms. Such terms turn the heterology of the South into a more limited expression of a regional eccentricity (for example, in the antebellum period the heterology of the poor white was often projected onto distorted, over-materialized bodies by the southwestern humorists) or into a regrettable break in the psychogenesis of the subject - the underlying critical assumption being that southern subjects are particularly broken and open to abjection in this regard. Patricia Yaeger, however, rightly argues that the presence of the southern grotesque or of an accent on "monstrosity" in southern literary writings "suggests a poverty within southern culture's political idiom - an idiom that is not enriched by change but made hysterical" and this implies a congealed gaze on the part of writers and critics that fixes on extreme formal schematizations (Yaeger 7). This "hysterical" history in the representation of the poor white is why Agee is morally averse to the grotesque as a way of depicting this class in Praise. In contrast to this physiognomic use of the grotesque, the force of the sacred in Agee or Caldwell (at least in Kent) is a mode of intensifying the heterogeneous part so as to bring out its subversive and material power.

Despite the fact that Georges Bataille is recognized as the major twentiethcentury theorist of the heterological, his work is hardly ever cited in critical commentary on southern literature. ${ }^{10}$ Yet Bataille is clearly relevant in locating such southern critical terms as the abject within a larger political and transatlantic context. Such a context is particularly applicable to the southern literature of the cotton tenant because it was the textile industry that connected the southern proletariat to precarious global markets, markets that in the 1930s were driving the price of cotton down. This is Agee's emphasis: "[T]he economic source" of the tenants" plight "is nothing so limited

10 For Bataille, who coined the concept of the abject in 1934, abjection is the exclusion of one class by another dominant class, which henceforth considers the abjected class as convertible with dirt. His scheme of abjection does not have any reference to the psychoanalytic drama of maternal absorption found in the adoption of his work by Kristeva, an adoption which has been seized upon by critics of southern literature without going back to Bataille as source (for the question of Kristeva's changes to Bataille see Kristeva and Lotringer). Bataille's philosophy of base materiality seems too sharply political for southern studies, even if these do often focus on the southern body and on trash phenomena. Bataille is even absent from Patricia Yaeger's Dirt and Desire: Reconstructing Southern Women's Writing, 1930-1990 (2000), a ground-breaking study that directed attention to the role of "dirt" in southern fiction as a marker of social exclusion in the region (Yaeger prefers to invoke Mary Douglas and Julia Kristeva, probably more limited guides when considering dirt as the "stuff of rebellion" than Bataille [Yaeger 265, 80]). Jay Watson's Reading for the Body: The Recalcitrant Materiality of Southern Fiction, 1893-1985 (Athens: U of Georgia $P, 2012$ ) aligns the study of the Southern Renaissance with the new materialisms of recent critical thought, a necessary counterbalance to a long critical preoccupation with the "mind" of the South, but it also makes no reference to Bataille. 
as the tenant system but is the whole world-system of which tenantry is one modification" (Agee, Praise 207-208).

Bataille's relevance to the literature of southern transgression can be seen, notably, in his contribution to the concept of "bare life," a concept which emerged after the First World War in such writers as Walter Benjamin. ${ }^{11}$ It specified a new kind of biopolitical vulnerability of the body on the part of some European peoples of the interwar years, particularly stateless peoples who were not offered the legal protection of citizenship. Agee was sensitive to the transatlantic implications of this figure of exposure. Writing notes for Praise at the beginning of the Second World War, he observed that every second of the tenants' lives "contain[ed] a dreadfulness to equal the whole of war" and his way of presenting the families as under siege from a militarized nature serves to make the South a home front in an international conflict (Agee, $R e$ discovered 149). Caldwell made an analogous point in a tract, Tenant Farmer (1936), when he said that in parts of the Depression South "human existence has reached its lowest depths" (Caldwell, Tenant 3). The sacrificial nature of this "bare life" lies behind Agee's frequent use of the Crucifixion to evoke the lives of his tenants: he says, for example, that "those three hours upon the cross are but a noble and too trivial an emblem" for their endurance (Agee, Praise 100). Here the way that Bataille brings the concept of sacrifice into the center of thinking about modernity is relevant. For "bare life" would be the result of the modernization of the concept of sacrifice within a secular age: where there is no theological return on the investment of sacrifice, the sacrificial act turns in on the self and renders it "an open wound, an exposure" - a life as continuous sacrifice without returns (Ffrench 75).

All this does not make Agee and Caldwell's South a kind of bleak cul-de-sac. The left hand sacred can become a positive force. A social repression or taboo is an ambivalent juncture in which the energy of repression can become an energy of contagion. Hence these two authors, in addition to their emphasis on the tragic consequences of exposure of the body, also present the Dionysian aspects of sacred expenditure. Agee sees in the damaged tenants the reversible principle of joy - and this is in keeping with Bataille's statement "I teach the art of turning anguish into delight" (Bataille, Inner 35). In Praise one manifestation of this sacred effervescence is as a solar principle, since the sun is a centre of energy that expends itself without return. Thus George Gudger's overalls are turned by backbreaking labor into a reflective fabric that is "as intricate and fragile, and as deeply in honor of the reigning sun, as the feather mantle of a Toltec prince" (Agee, Praise 268). At the conclusion of the book Agee has a final reference to the sleeping child, Ellen Woods, her umbilical "circle" exposed and issuing "a snoring silence of flame" that "shall at length outshine the sun" (Agee, Praise 442). It is in allegiance to this immanent religion of the sun as excess that Agee calls on William Blake as an "unpaid agitator" and on his principle that "The road of excess leads to the palace of wisdom" (Agee, Praise xxii, 458).

This Dionysianism of the earth is also present in Caldwell. Of course the Dionysian might not be immediately apparent in a family like the Lesters in Tobacco Road. They are so shiftless and numbed with repetitive habit as to have a virtually

11 The term "bare life" is explored in its interwar manifestations in Giorgio Agamben, Homo Sacer: Sovereign Power and Bare Life. Trans. Daniel Heller-Roazen (Stanford: Stanford UP, 1998). 
pathological relationship with the real: this is caught in Jeeter's fruitless attempts to sell worthless blackjack wood or the unregarded way the grandmother is accidentally run over by Bessie's car and left to die. In such scenes Caldwell seems to be derisively watching his characters inch toward the condition of trash objects, like the unsold wood that is eventually burnt by Jeeter in the ditch. But this near psychotic relationship to the real suddenly swings round in the Lesters' favor, and the joke is on the knowing reader, if that real is seen as utilitarian or servile and therefore worthy of rejection. In this light Jeeter Lester's instinctive clinging to the land is not only a wasteful attachment to a pre-modern economy, but also a sort of Dionysian observance in a collective religion of the earth. Jeeter's own accidental immolation in a scrub-clearing fire at the end of the novel seems like an assimilation to this cyclical earth and one where fire and sun have played mediator. As Lov Bensey says in a simple eulogy to the doggedness of Jeeter, his father in law, in trying to raise a crop: Jeeter "was a man who liked to grow things in the ground" (Caldwell, Tobacco 169). Caldwell and Agee are attuned not only to the tenants' inefficiencies within a rational economy but to an ecological economy based on surplus and gift. In this they are in keeping with Bataille, whom as Jürgen Habermas says, "opposes to this particular scarcity-based viewpoint the general viewpoint of a cosmically expanded energy ecology" (Habermas 234). Even the Lesters' apparent obtuseness in their demolition by stages of Bessie's new car, reappears in this symbolic scheme as a justified hostility to the invasive modern commodity - goods whose price has been inflated by tariffs and which keep the region in a state of colonial dependency.

A collective religion of the sun appears in one of Caldwell's most remarkable short stories, "Kneel to the Rising Sun" (1935). Lonnie, a white tenant, lives in near starvation because he dare not ask his landlord for scraps of food; his friend Clem, a more forceful black tenant of the same landlord, reproves Lonnie's docility. Clem's rebelliousness finally leads to him being pursued by the landlord and a lynching party. Clem's hiding place is betrayed by Lonnie, who reverts to an instinctive race solidarity with other whites at this moment of crisis. As Lonnie flees the lynching scene, he seems to absorb momentarily a transgressive, cross-racial spirit from the rising sun, even a revolutionary form of what Bataille called "non-knowledge" (Bataille, Inner 52): Lonnie "struggled to this knees, facing the round red sun. The warmth gave him the strength to rise to his feet, and he muttered unintelligibly to himself. He tried to say things he had never thought to say before" (Caldwell, "Kneel"). These "things he had never thought to say before" belong to an inexpressible political thinking that at this moment of stress almost comes into expression. Lonnie's rebelliousness, however, peters out and he returns to his former obsequiousness toward the landlord.

Caldwell's final accent in the story on the failure of multi-racial solidarity is true to the deep-rootedness of segregation in the interwar South and is a repudiation of the demands of propaganda art (one reviewer of American Earth in The New Masses had urged Caldwell to "go left" [quoted in Cook 35]). It is significant that these three writers of the sacred in the 1930s - Caldwell, Agee and Bataille - were not literary Communists. Bataille moved at the end of this decade away from the street-fighting militancy of the Contra-Attaque group to founding a secret society, Acéphale, which tried to introduce the sacred surreptitiously into the French body politic. Agee's un- 
derstanding of the sacred as self-dispossession also took him far from the ideal of the fused community sought by the Communist party or indeed sought, in different variations, by the New Deal or by Nashville Agrarianism.

For Agee, the three tenant families, in their isolation behind "shell and carapace" (Agee, Praise 53), do not belong so much to a corporate community as to what Bataille called "the community of those who have no community" (quoted in Blanchot 25). Bataille's paradoxical idea of the community was worked out as a consequence of the failure of Communism in the late 1930s. This line of Bataille's thinking, with the impossible demand to unite the wounded separation of individuals and the Durkheimian "social facts" of the group, was taken up by Jean-Luc Nancy and Maurice Blanchot with their concept of an "inoperative" community (Durkheim 231). ${ }^{12}$ Agee's tenants can be considered as participants of this "inoperative" community. In Praise the self is indissolubly bound to a neighbor not in the sense of fusion, but as to one whose very otherness and susceptibility to death takes the self out of itself (in a relation of wounding or loss). That is why in the late section of Praise, "Shady Grove, Alabama, July 1936," the "inoperative" community of tenants seems to cohere around, and have its centre of being, in a graveyard and in such emptied-out grave memorials as a "blown bulb" (Agee, Praise 438).

This article has tried to show how both Agee in Praise and Caldwell in Kent saw the otherness of southern poverty in the Depression through the sacred and particularly the politicized sacred of Georges Bataille. They could do this because they inherited a similar Christian imaginary of the exposed, sacrificial body as did Bataille and applied its logic of loss to the South. The southern soil serves as the matrix of this sacred - for Caldwell and Agee it is their primary instance of "the base earth, domain of pure abjection" (Bataille, Visions 42). So well did Agee communicate this quality of southern and transnational abjection that Dwight Macdonald could describe Praise in 1948 as a "Works and Days of our times" and see Agee as a Hesiod for the modern necro-agriculture; he even compared Agee's tenants and their "way of death" to the inmates of "Nazi and Soviet concentration camps" (Macdonald 124-125). But the work of Bataille on expenditure shows that the writings of Agee and Caldwell cannot only be regarded as sheer loss within a rational economic model. They also appeal to a preutilitarian type of collective life where "sociality is equivalent to expenditure beyond productive utility" (Ffrance 31). Caldwell's Ty Ty Walden with his fruitless digging for gold on his land, or the credit-poor Jeeter Lester, or Alan Kent the farm laborer, are failures in their attempts to reap wealth from an unproductive southern earth, but the anguished totality of their commitment is also a form of sacred expenditure on "God's little acre." Agee's tenants likewise display the "royalty" of an older sovereignty of the self rather than of state power, a sovereignty that belongs to a religion of the sun (Agee, Praise 415).

12 Jean-Luc Nancy, The Inoperative Community. Minneapolis: U of Minneapolis P, 1991; Maurice Blanchot (in works cited). 


\section{Works Cited}

\section{Primary Works}

Agee, James. James Agee Rediscovered. The Journals of Let Us Now Praise Famous Men and Other New Manuscripts. Ed. Michael A. Lofaro and Hugh Davis. Knoxville: U of Tennessee P, 2005. Print.

Agee, James and Walker Evans, Let Us Now Praise Famous Men. Boston: Houghton Mifflin, [1941] 1960. Print.

Bataille, Georges. Inner Experience. Trans. Leslie Anne Boldt. Albany: State U of New York P, 1988. Print.

. Visions of Excess. Selected Writings, 1927-1939. Ed. Allan Stoekl. Trans. Allan

Stoekl, Carl R. Lovitt and Donald M. Leslie, Jr. Minneapolis: U of Minnesota P, 1985. Print.

Caldwell, Erskine. Conversations with Erskine Caldwell. Ed. Edwin T. Arnold. Jackson: UP of Mississippi, 1988. Print.

. God's Little Acre. New York: Modern Library, 1933. Print.

. "Kneel to the Rising Sun." xroads.virginia.edu/ ma01/White/anthology/caldwell. html Web. 15 Aug. 2018.

. Tenant Farmer. New York: Phalanx Press, 1935. Print.

. The Sacrilege of Alan Kent. Portland: Falmouth Book House, 1936. Print.

. Tobacco Road. New York: New American Library, [1932] 1962. Print.

\section{Secondary Works}

Blanchot, Maurice. The Unavowable Community. Trans. Pierre Joris. New York: Station Hill P, 1988. Print.

Cook, Sylvia Jenkins. Erskine Caldwell and the Fiction of Poverty: The Flesh and the Spirit. Baton Rouge: Louisiana State UP, 1991. Print.

Davis, Hugh. The Making of James Agee. Knoxville: U of Tennessee P, 2008. Print.

Duck, Leigh Ann. "Arts of Abjection in James Agee, Walker Evans, and Luis Buñuel." The Oxford Handbook of the Literature of the U.S. South. Eds. Fred Hobson and Barbara Ladd, New York: Oxford UP, 2016. 290-309. Print.

. The Nation's Region: Southern Modernism, Segregation, and U.S. Nationalism. Athens: U of Georgia P, 2006. Print.

Durkheim, Emile. The Elementary Forms of the Religious Life. Trans. Joseph Ward Swain. London: George Allen and Unwin, 1915. Print.

Ffrench, Patrick. After Bataille. Sacrifice, Exposure, Community. Abingdon: Modern Humanities Research Association and Routledge, 2007. Print.

Gasché, Rodolphe. Georges Bataille: Phenomenology and Phantasmatology. Trans. Roland Végső. Stanford: Stanford UP, 2012. Print.

Habermas, Jürgen. The Philosophical Discourse of Modernity: Twelve Lectures. Trans. Frederick G. Lawrence. Cambridge: MIT Press, 1990. Print.

Jannson, David R. "Internal orientalism in America: W.J. Cash's The Mind of the South and the Spatial Construction of American National Identity." Political 
Geography 22 (2003): 293-316. Elsevier Science Direct. Web. 15 Aug. 2018.

Kristeva, Julia and Sylvère Lotringer, "Julia Kristeva in Conversation with Sylvère Lotringer." semiotexte.com. Web. 21 Nov. 2018.

Laughlin, James, ed. New Directions in Prose and Poetry 1940. Norfolk: New Directions, 1940. Print.

Leuchtenburg, William E. The White House Looks South: Franklin D. Roosevelt, Harry S. Truman, Lyndon B. Johnson. Baton Rouge: Louisiana State U Press, 2005. Macdonald, Dwight. “After Seven Years.” Politics (Spring 1948), 123-125. Print.

Owen, Guy. "The Sacrilege of Alan Kent and the Apprenticeship of Erskine Caldwell." Literary Journal 12.1 (Fall 1979) 36-46. JSTOR. Web. 15 Nov. 2015.

Raper, Arthur F and Ira De A. Reid, Sharecroppers All. Chapel Hill: U of North Carolina Press, 1941. Print.

Vials, Chris. "Whose Dixie? Erskine Caldwell's Challenge to Gone with the Wind and Dialectical Realism." Criticism No 1 (2006): 69-94. Project Muse. Web. 15 Aug. 2018.

Yaeger, Patricia. Dirt and Desire: Reconstructing Southern Women's Writing, 19301990. Chicago: U of Chicago P, 2000. Print. 